\title{
Role of Health and Safety Management Practices in Safety Performance of Malaysian Bumiputera SMEs
}

Iskandar Hasan Tan Abdullah, Sakinah Mat Zin, Rosfatihah Che Mat, W. Nurfahizul Ifwah W. Alias

To Link this Article: http://dx.doi.org/10.6007/IJARBSS/v12-i1/11854

DOI:10.6007/IJARBSS/v12-i1/11854

Received: 09 November 2021, Revised: 01 December 2021, Accepted: 23 December 2021

Published Online: 02 January 2022

In-Text Citation: (Abdullah et al., 2022)

To Cite this Article: Abdullah, I. H. T., Zin, S. M., Mat, R. C., \& Alias, W. N. I. W. (2022). Role of Health and Safety Management Practices in Safety Performance of Malaysian Bumiputera SMEs. International Journal of Academic Research in Business and Social Sciences, 12(1), 11-25.

Copyright: (c) 2022 The Author(s)

Published by Human Resource Management Academic Research Society (www.hrmars.com)

This article is published under the Creative Commons Attribution (CC BY 4.0) license. Anyone may reproduce, distribute, translate and create derivative works of this article (for both commercial and non0-commercial purposes), subject to full attribution to the original publication and authors. The full terms of this license may be seen at: http://creativecommons.org/licences/by/4.0/legalcode

Vol. 12, No. 1, 2022, Pg. $11-25$

Full Terms \& Conditions of access and use can be found at http://hrmars.com/index.php/pages/detail/publication-ethics 


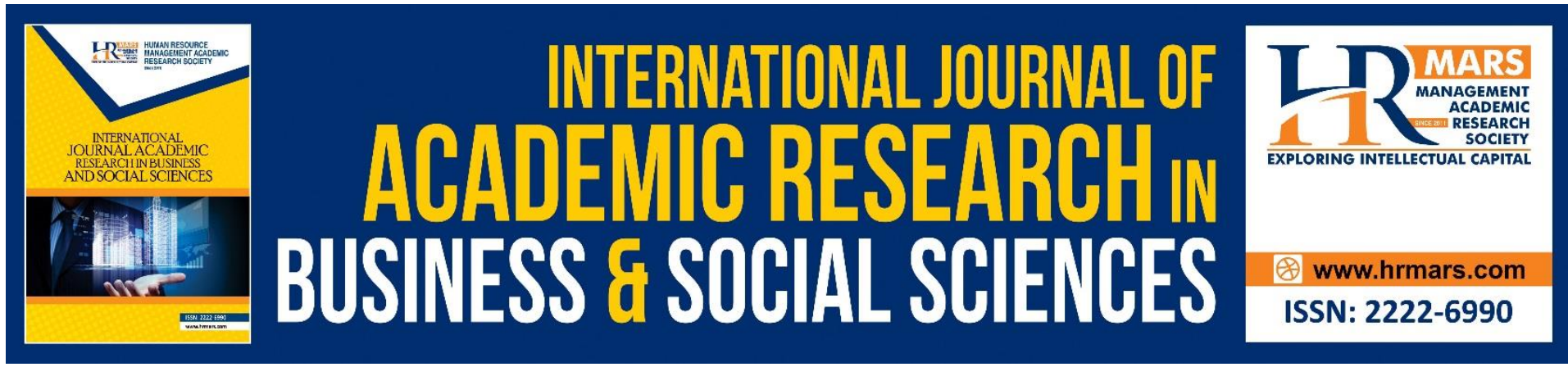

\title{
Role of Health and Safety Management Practices in Safety Performance of Malaysian Bumiputera SMEs
}

\author{
Iskandar Hasan Tan Abdullah¹, Sakinah Mat Zin², Rosfatihah \\ Che Mat ${ }^{3}$, W. Nurfahizul Ifwah W. Alias ${ }^{4}$ \\ ${ }^{1}$ Faculty of Administrative Science and Policy Studies, ${ }^{2}$ Faculty of Business and Management, ${ }^{3}$ Faculty \\ of Computer \& Mathematical Sciences, Universiti Teknologi MARA, Kelantan, Malaysia. \\ Corresponding Author Email: sakin405@uitm.edu.my
}

\begin{abstract}
Small and medium enterprises (SMEs) are widely acknowledged as the backbone of the Malaysian economy. Therefore, it is very important that SMEs manage occupational health and safety adequately. The purpose of this paper is to investigate safety management practices and its associations with the safety performance in Malaysian Bumiputera SMEs. A safety management system reflects the organization's commitment to safety which will result in improved safety performance; thus, it is worth investigating. In particular, this study aims to determine the relationship of safety management practices (entrepreneur's commitment, safety training, worker's involvement in safety, safety communication, safety rules and procedures, and safety promotion policies) and safety performance (safety compliance and participation). In doing so, survey questions from previous studies are adopted and customized to collect data. The sample of 272 Bumiputera SME entrepreneurs is utilized, and the data are analysed using SPSS version 27 . The results of the study reveal that safety management practice facets i.e., safety rules and procedures, safety communication, and entrepreneur commitment significantly influence safety performance. While safety promotion, worker involvement and safety training are not useful to the prediction of safety performance. This enables practitioners and scholars to comprehend and make appropriate decisions that can enhance safety performance among Bumiputera SME entrepreneurs in Malaysia.
\end{abstract}

Keywords: Health and Safety Management, Bumiputera, SME, Safety Performance

\section{Introduction}

Malaysia has launched Occupational Safety and Health Master Plan 2021 - 2025 (OSHMP2025), which consists of 7 strategies altogether. 51 programs include SME, advanced technology, R\&D, new sectors are given prominence to Strategy 5 i.e., mainly about improving OHS compliance in the SME sector (DOSH, 2021). Hence, Bumiputera SMEs should receive the right guidance, training, and financial support for the OHS obligations.

Occupational accidents in SMEs are more common than large firms (Dugolli, 2021; NowrouziKia, Nadesar, \& Casole, 2019). Small enterprises, on the whole, are susceptible to operate 
without regular work practices (Breslin et al., 2010) or administrative assistance (Eakin \& Mykhalovskiy, 2003). As a result, the risks of accidents and injuries in the workplace are much higher in SMEs because they tend to operate in a more dangerous work environment than large organizations. Compared to large companies, fatal accidents are up to eight times more common in SMEs, and non-fatal injuries are up to 50\% more likely (Tremblay \& Badri, 2018). Some of these potential hazards can destroy a business. So, it is critical to incorporate safety practices by applying crisis management (Iqbal et al., 2021). The lack of OHS management is justified by $90 \%$ of SMEs (Caldarescu et al., 2021). However, gaps still exist between the high percentage of SMEs and the firms' safety performance. In actual fact, SMEs frequently have scarce knowledge, time, and resources (Kelloway, Kelloway, \& Cooper, 2011) to appropriately address $\mathrm{OHS}$ issues.

The management of OHS and the organisational environment in SMEs is not well documented and is likely to be informal and ambiguous. The safety management system in SMEs, on the other hand, is not as complex as that found in large organisations. It is highly doubtful that proper safety management exists in SMEs (Al Mawli et al., 2021), particularly Bumiputera SMEs. Greater attention must be given to OHS compliance in order to reap the benefits of improved SME performance and safety (Hou et al., 2021). Since Bumiputera are the critical subject to be addressed and become the main agenda of the government, it is important for a study to be conducted to ascertain the extent of Bumiputera SME entrepreneurs in upholding health and safety management practices to meet the emerging challenges of creating better working environments.

Unfortunately, there is lack of studies carried out in Malaysia to assess the safety performance of SMEs. In fact, previous research has paid less attention to the demand of statistical evidence, which has hampered the advancement of OHS management in SMEs (Ramos, Afonso \& Rodrigues, 2020). Thus, it warrants for a study to learn what the inclination of Bumiputera OHS management practices is; and how these activities influence the safety performance. Answers to these questions are important as they provide greater insight into SME OHS from both a theoretical and practical standpoint.

Hence, the motivation for this study is to help the Malaysia Bumiputera SMEs in upgrading their knowledge and business outlook. This also could help them in increasing their business profit through the better health and safety management performance and practices. Bumiputera SMEs need to allocate relatively more time to OHS, be aware of OHS issues and more advanced in their activities in support of OHS. Simply, spending more time on OHS would appear to provide significant benefits improving the business' health and safety. In particular, this study aims to examine the effect of health and safety management practices (entrepreneur's commitment, safety training, worker's involvement in safety, safety communication, safety rules and procedures, and safety promotion policies) on safety performance (safety compliance and participation) among Bumiputera SME entrepreneurs. Additionally, a model of Bumiputera SME safety performance is created by taking into account the OHS management practices as it may provide better guidance to the new Bumiputera entrepreneurs to carve the same safety success. To do this, the study seeks upon two theories, namely Heinrich's Domino Theory and Resource-based View (RBV) Theory.

H.W. Heinrich developed Heinrich's domino hypothesis, or the Domino Theory of accident causation, in the 1930s. Accidents, according to this view, are predictable sequences of occurrences. Each causal element reinforces the effects of the previous ones. Bird \& Loftus (1976) has highlighted that the management is responsible for the workers' safety and wellbeing. In other words, contact situations could be prevented if risky activities were avoided. 
Moreover, the RBV benefits health and safety management by focusing on the importance of human capital in strategic planning and safety management procedures. The RBV promotes safety management methods and their impact on firm resources (Delery, 1998; Wright, Dunford \& Snell, 2001). As for this study, the concept of safety management capabilities is used to analyze the safety performance success of the firm.

Intriguing to examine the degree of OHS management practices Bumiputera SMEs have and whether these practices can encourage safety performance, the present study is presented as follows. First, the research examines the previous literatures. Next, methodology and descriptive analysis are described. Experience and perceived performance then follow. Finally, the paper concludes with results, discussion, and implications.

\section{Literature Review \\ Safety Performance}

Safety performance influences the safe activities of employees at various organizational levels (Zohar \& Erev, 2007). SME entrepreneur's leadership behaviour has a significant impact on safety performance (Asad et al., 2021). Griffin \& Neal (2000) asserted two distinct forms of safety behaviors: safety participation and safety compliance. Therefore, this study has established that the leadership of Bumiputera SME entrepreneurs plays an imperative role in influencing organizational safety performance, in terms of safety participation and safety compliance.

\section{Safety Management Practices}

There are six components of safety management practices i.e., management commitment, safety training, worker's involvement, safety communication and feedback, safety rules and procedures, and safety promotion policies (Subramaniam et al., 2016). Zulkifly et al (2021b) have emphasized the importance of owner-manager safety management practices in driving safety performance and demonstrates how each dimension of safety management practices either improves or hinders safety performance.

Increased managerial safety commitment, such as concerns about workers' safety participation activities and participation safety activities, will directly motivate workers to participate in safety (Su, 2021). However, Setyawan, Nainggolan \& Fauzi (2021) claim that management commitment and leadership variables have no significant effect on safety performance.

Employee participation and training have a significant positive impact on safety performance (Setyawan et al., 2021). Similarly, Wahab et al (2014)'s findings show that safety training practises have a significant impact on an organization's safety performance. Sukamani, Wang $\&$ Kusi (2021) had shown how safety training moderated the relation between safety worker behaviour \& safety performance.

Ünal et al (2019) conducted a study on workers in Turkish manufacturing companies, finding a positive relationship between employee work involvement and safety performance. The same findings can be found in a study conducted by Hong et al (2018), which found that workers' involvement in the Malaysian manufacturing industry has a positive influence on safety performance.

Hale, Heijer \& Koornneef (2003) identified safety communication between managers and employees as one of five desirable management safety practices, which differentiated between low and high accident rate postal delivery offices. Newaz et al (2021) mentioned 
that safety communication is in the second cluster of factors focuses on the workgroup's safety performance.

Safety rules and procedures provide critical guidelines for safety management practices in order to achieve positive safety outcomes (Wachter \& Yorio, 2014). The values and culture of an organization have a direct impact on the successful implementation of safety rules (Gao et al., 2018).

Effective safety concept promotion significantly improves employees' safety awareness (Lu, Poon \& Weng, 2018), increases the execution of safety regulations, and ensures that safetyrelated measurements and messages are precisely delivered to their target groups (Lin \& Chang, 2021).

\section{Methodology}

Cross-sectional survey design using a quantitative approach is adopted. All components of safety management are selected based on literature review. The questionnaire was adapted from Vinodkumar \& Bhasi (2010) and converted into an online survey instrument. By adopting the self-report survey method in Malaysia setting, not only the adaptability of the method that has previously been proven validate in India, is expanded, but the versatility of this approach is also improved. The questionnaire contained 29 questions to measure the perceptions of the Bumiputera SME entrepreneurs about the safety management practices, and 8 questions to measure self-rated safety compliance and safety participation. This was prepared based on review of related literature and theory and it contained questions covering areas of entrepreneur's commitment ( 8 items), safety training (5 items), workers' involvement in safety (4 items), safety communication (4 items), safety rules and procedures (4 items), safety compliance and safety participation ( 8 items).

The reliability of the instrument was tested to determine its measurement consistency with the study variables on the scales employed (Nunnally, 1978). Cronbach alpha coefficients of all variables exhibit acceptable reliability coefficients which are above 0.7 . To analyse the research model and check the hypothesis, multiple regression analysis was utilised. A oneway Analysis of Variance (ANOVA) was used to analyse datasets since it allows comparisons to be made between three or more groups of data.

It was decided to give the questions in Malay language based on the feedback from the entrepreneurs. Each item was assessed on a 1-7 Likert scale ( $1=$ 'strongly disagree' to $7=$ 'strongly agree'). When compared to a 10-point scale, a 7-point scale is likely to give slightly higher mean scores relative to the highest conceivable attainable score (Dawes, 2008).

The population for this research is Bumiputera SME entrepreneurs registered with the Malaysian Cooperative Commission (SKM) Kelantan. SKM Kelantan managed to generate a revenue of RM1.23 million in 2017. The achievement placed the cooperative movement in Kelantan in top 5 (Bernama, 2019). SKM is under the Ministry of Entrepreneur Development and Cooperatives (MEDAC) and categorized as SME. In fact, MEDAC has executed many economic intervention initiatives to support SMEs under SKM (Bernama, 2021).

There are 46,260 (5.1\% x 907,065) SME entrepreneurs in Kelantan (DOSM, 2020), 918 of them are Bumiputera SME entrepreneurs registered with Malaysia Co-operative Societies Commission (SKM), Kelantan. 272 SKM Bumiputera entrepreneurs in Kelantan were selected for the research sample, which exceeds the minimum of 269 sample size determined by Krejcie and Morgan (1970). As a matter of fact, a sample size of 30 to 500 is sufficient to conduct a research (Sekaran \& Bougie, 2019; Roscoe, 1975). The target population for this research is all sectors in the SME industry that covers the state of Kelantan. Prior studies on 
SME also have focused on specific state in Malaysia. For examples, Azzahra'Johari et al (2021) concentrated on SMEs in Johor; Othman, Ng \& Mohamad (2020) focused on SMEs that established and operate in the business in Melaka; and Nordin \& Lada (2020) conducted a study on SMEs in Labuan. Zulkifly et al (2021a) studied safety performance within the SME manufacturers in Selangor. There are 918 SME entrepreneurs enrolled in SKM Kelantan (Sais, 2020) (see table 1.0).

Table 1.0: Number of Bumiputera SME establishments for SKM in Kelantan

\begin{tabular}{lc}
\hline Business Sectors & Population \\
\hline Commerce and Services & 818 \\
Manufacturing & 47 \\
Construction & 39 \\
Agriculture & 10 \\
Mining and Quarrying & 4 \\
Total & 918 \\
\hline
\end{tabular}

Source: Sais (2020)

The study adopted stratified sampling approach that divides the population into a number of relevant strata, each of which is proportionally represented within the sample (Saunders et al., 2009). The population is distributed into 5 business sectors using a proportionate stratified sample method.

When compared to the overall population, the sample size of each stratum is proportional to the population size of the stratum. This means that the sampling fraction in each stratum is the same. Each stratum's sample size is calculated by multiplying its population size by 0.296 (i.e., 272/918). (see table 2.0). As a result, the population and sample size for the strata are as follows:

Table 2.0: Population and Sample Size for SKM Bumiputera SMEs in Kelantan

\begin{tabular}{lll} 
Business Sectors & Population & Sample \\
\hline Commerce and Services & 818 & 242 \\
Manufacturing & 47 & 14 \\
Construction & 39 & 12 \\
Agriculture & 10 & 3 \\
Mining and Quarrying & 4 & 1 \\
Total & 918 & 272
\end{tabular}

\section{Descriptive Analysis}

Table 3.0 and figure 1.0 presents the age and education of SKM Bumiputera SME entrepreneurs. The results of this study indicate $58.1 \%$ of SKM entrepreneurs are between 29-48 years of age, hence categorised into generation $Y$ (born after 1980), generation X (1970 to 1980) and generation $Z$ (born 1996 to 2010). This suggests that their age is likely influencing safety management practices and safety performance. Entrepreneurs in generation $X, Y$ and $Z$ are technologically savvy, team-oriented, and flexible (Benson \& Mitchell, 2011), risk-takers with excellent leadership skills (Yazici \& Ayazlar, 2021). Singh Ghura (2017) claimed that generation $Z$ had associated challenges with retention and providing good quality work. Such discrete features therefore largely influence the safety management practices.

Table 3.0: Age and Education of the Entrepreneurs 


\begin{tabular}{lll}
\hline Age & Total & Percent \\
19-28 years old & 30 & 11.0 \\
29-38 years old & 77 & 28.3 \\
39-48 years old & 81 & 29.8 \\
49-58 years old & 57 & 21.0 \\
59-68 years old & 27 & 9.9 \\
& & \\
Education & & \\
PhD & Total & Percent \\
Master & 1 & 0.4 \\
Bachelor & 15 & 5.5 \\
Diploma & 57 & 21.0 \\
SPM/STPM & 74 & 27.2 \\
Others & 100 & 36.8 \\
Total & 25 & 9.2 \\
\hline
\end{tabular}

Figure 1.0: Age And Education of the Entrepreneurs

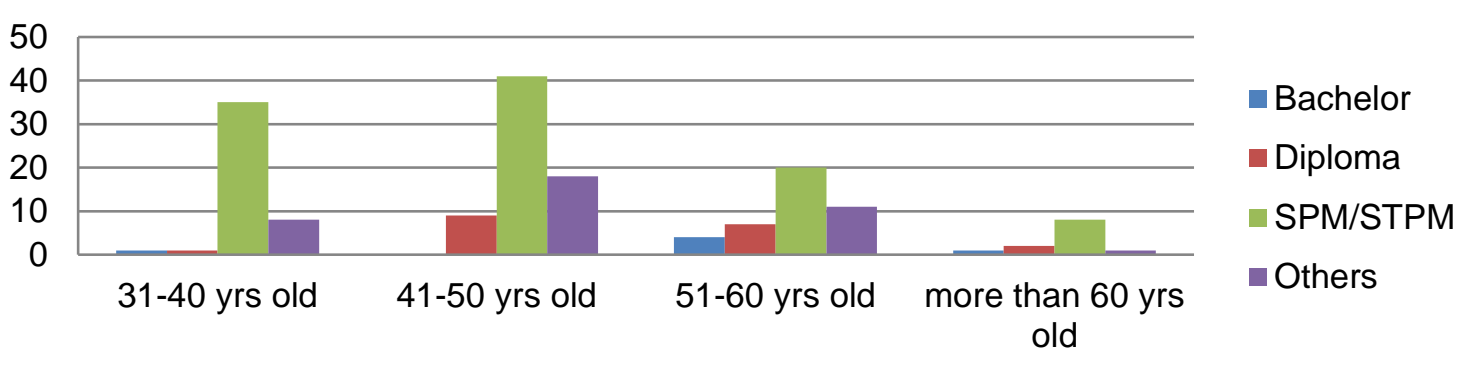

For the education level, $36.8 \%$ of the entrepreneurs have finished secondary school, $27.2 \%$ have diploma, $21 \%$ possess bachelor's degree $5.9 \%$ possess master's and PhD. Clearly, there exist quite a considerable percentage of them having tertiary level of education. Entrepreneurs stressed the importance of education, noting that there are numerous ways for an entrepreneur to obtain an education (Dumitrașciuc, 2019). 90.8\% of SKM entrepreneurs have basic minimum qualifications of SPM/STPM that are required for the management position. As this study attempts to integrate OHS management practices into the safety performance, there is need for more educated entrepreneurs who can align these two issues in order to attain sustainable profitability.

\section{Experience and Perceived Performance}

More than half of the entrepreneurs have business experience less than 6 years. $20.2 \%$ have been working for 6 to 10 years, $8.5 \%$ for 11 to 15 years and $10.7 \%$ above 15 years. These figures tell that almost all SKM Bumiputera entrepreneurs possess business experience which would make them persevere, able to keep safety as a critical component in developing a highperforming, sustainable business environment. 
Table 4.0: Business Experience and Average Monthly Sales

$\begin{array}{lll}\text { Business Experience } & \text { Total } & \text { Percent } \\ \text { Less than 1 year } & 46 & 16.9 \\ \text { 1-5 years } & 119 & 43.8 \\ \text { 6-10 years } & 55 & 20.2 \\ \text { 11-15 years } & 23 & 8.5 \\ \text { 16-20 years } & 20 & 7.4 \\ \text { more than 20 years } & 9 & 3.3 \\ \text { Total } & 272 & 100.0 \\ & & \\ \text { Average Monthly Sales } & \text { Total } & \text { Percent } \\ \text { RM1,000-RM10,000 } & 150 & 55.1 \\ \text { RM11,000-RM20,000 } & 52 & 19.1 \\ \text { RM20,001-RM30,000 } & 25 & 9.2 \\ \text { RM30,001-RM40,000 } & 8 & 2.9 \\ \text { RM40,001-RM50,000 } & 13 & 4.8 \\ \text { more than RM50,000 } & 24 & 8.8 \\ \text { Total } & 272 & 100.0\end{array}$

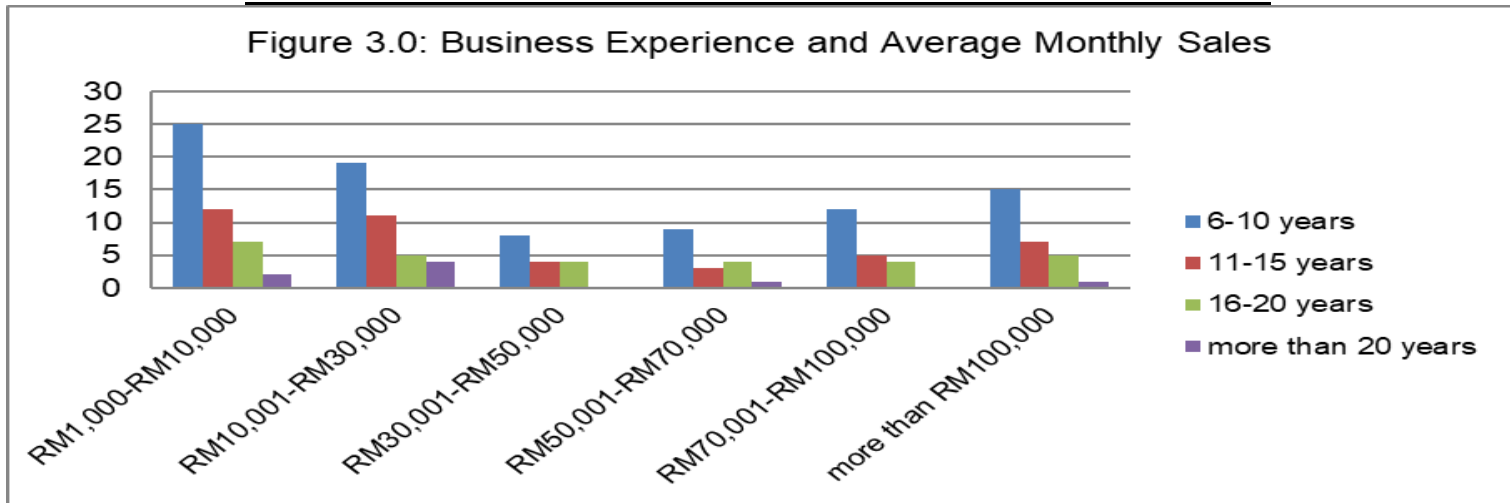

According to Jenkins, Kane \& Velury (2004), firms can be divided into five life cycle groups: start-up (below 5 years), growth (6-10 years), growth/mature (10-15 years), mature/decline (16-20 years) and decline (above 20 years). Most SKM SME companies are at the start-up and growth level. These companies attained the average monthly sales of RM1,000-RM10,000. At this stage, their business has demonstrated that it is a workable business entity by having enough customers who can be satisfied sufficiently with their products or services.

\section{Results and Discussion}

Correlation analysis is performed to estimate the value of a variable and measure the degree of relationship (positive or negative) between the variables. Correlation is important in establishing a causal relationship. Pallant (2013) found that a correlation of 0 means irrelevant and a correlation of 1.0 indicates a perfect positive correlation. Correlation -1.0, on the other hand, represents a completely negative relationship. Table 6.0 shows correlation results among the variables, namely safety performance (dependent variable) and entrepreneur commitment, safety training, worker's involvement, safety communication, safety rules and procedures, and safety promotion policies (independent variables).

Table 5.0: Correlations among the Variables 


\begin{tabular}{|c|c|c|c|c|c|c|c|}
\hline & $\begin{array}{l}\text { Safety } \\
\text { perf } \\
\text { orma } \\
\text { nce }\end{array}$ & $\begin{array}{l}\text { Safety_- } \\
\text { promotio } \\
\text { n }\end{array}$ & $\begin{array}{l}\text { Safety_ } \\
\text { rules_- } \\
\text { procedure } \\
\text { s }\end{array}$ & $\begin{array}{l}\text { Safety_ } \\
\text { commu } \\
\text { nicatio } \\
\mathrm{n}\end{array}$ & $\begin{array}{l}\text { Worker_i } \\
\text { nvolveme } \\
\text { nt }\end{array}$ & $\begin{array}{l}\text { Safety } \\
\text { trainin } \\
\text { g }\end{array}$ & $\begin{array}{l}\text { Entrepren } \\
\text { eur_com } \\
\text { mitment }\end{array}$ \\
\hline $\begin{array}{l}\text { Safety_ } \\
\text { performanc } \\
\text { e }\end{array}$ & 1 & $.607^{* *}$ & $.867^{* *}$ & $.807^{* *}$ & $.742^{* *}$ & $.768^{* *}$ & $.735^{* *}$ \\
\hline $\begin{array}{l}\text { Safety_ } \\
\text { promotion }\end{array}$ & $.607^{* *}$ & 1 & $.698^{* *}$ & $.621^{* *}$ & $.765^{* *}$ & $.682^{* *}$ & $.513^{* *}$ \\
\hline $\begin{array}{l}\text { Safety_ } \\
\text { rules_- } \\
\text { procedures }\end{array}$ & $.867^{* *}$ & $.698^{* *}$ & 1 & $.843^{* *}$ & $.817^{* *}$ & $.795^{* *}$ & $.707^{* *}$ \\
\hline $\begin{array}{l}\text { Safety_com } \\
\text { munication }\end{array}$ & $.807^{* *}$ & $.621^{* *}$ & $.843^{* *}$ & 1 & $.803^{* *}$ & $.766^{* *}$ & $.683^{* *}$ \\
\hline $\begin{array}{l}\text { Worker_- } \\
\text { involvemen } \\
t\end{array}$ & $.742^{* *}$ & $.765^{* *}$ & $.817^{* *}$ & $.803^{* *}$ & 1 & $.835^{* *}$ & $.672^{* *}$ \\
\hline $\begin{array}{l}\text { Safety_ } \\
\text { training }\end{array}$ & $.768^{* *}$ & $.682^{* *}$ & $.795^{* *}$ & $.766^{* *}$ & $.835^{* *}$ & 1 & $.745^{* *}$ \\
\hline $\begin{array}{l}\text { Entreprene } \\
\text { ur_commit } \\
\text { ment }\end{array}$ & $.735^{* *}$ & $.513^{* *}$ & $.707^{* *}$ & $.683^{* *}$ & $.672^{* *}$ & $.745^{* *}$ & 1 \\
\hline
\end{tabular}

Cohen, Cohen, West \& Aiken (2003) provide guidelines for interpreting correlation values.

Table 6.0: Correlation Values Interpretation

$r=0.10$ to 0.29 or $r=-0.10$ to -0.29 small

$r=0.30$ to 0.49 or $r=-0.30$ to -0.49 moderate

$r=0.50$ to 1.00 or $r=-0.50$ to -1.00 substantial

Table 5.0 and Table 6.0 show correlation analysis results using Pearson correlation based on statistically significant one-tailed test at $99 \%$. In general, the results indicated that all variables were positive and significant. The strongest relationship was between safety rules and procedures and safety performance $(r=0.867, p<0.01)$, followed by correlation between safety rules and procedures and safety communication $(r=0.843, p<0.01)$. The weakest relationship was safety promotion and safety performance $(r=0.607, p<0.01)$. Still, all correlation values were classified as substantial (Cohen et. al., 2003).

Further, a multiple regression analysis was conducted to investigate the relationship between intellectual capital and corporate performance. A one-way ANOVA table was created, showing regression analysis with degrees of freedom. A P-value $\leq \alpha$ means that the difference between some means is statistically significant. Coincidentally, there was a significant difference in the average value $[F(6,264)=171.9, p<0.001]$ between the variables. $F$ statistic is a test of significance for the entire regression. Since the result shows that $p$-value $<0.05$, this regression is statistically significant. 
Table 7.0: ANOVA for Safety Performance

\begin{tabular}{|c|c|c|c|c|c|c|}
\hline \multicolumn{2}{|c|}{ Model } & $\begin{array}{l}\text { Sum } \\
\text { Squares }\end{array}$ & of $\mathrm{df}$ & $\begin{array}{l}\text { Mean } \\
\text { Square }\end{array}$ & $\mathrm{F}$ & Sig. \\
\hline \multirow[t]{3}{*}{1} & Regression & 133.833 & 6 & 22.306 & 171.894 & $<.001^{b}$ \\
\hline & Residual & 34.258 & 264 & .130 & & \\
\hline & Total & 168.091 & 270 & & & \\
\hline \multicolumn{7}{|c|}{$\begin{array}{l}\text { D. } \\
\text { Safety_communication, } \\
\text { Worker_involvement }\end{array}$} \\
\hline
\end{tabular}

Table 8.0: Multiple Regression Results for Safety Performance

Model Standardized Coefficients

t Sig.

\section{1 (Constant)}

Safety_promotion

Safety_rules_procedures

Safety_communication

Worker_involvement

Safety_training

Entrepreneur_commitment
Beta

$-.016$

.550

.199

$-.072$

.112

.184
$2.350 \quad .020$

$\begin{array}{ll}-.352 & .725\end{array}$

$8.946<.001$

$3.504<.001$

$-1.122 \quad .263$

$1.914 \quad .057$

$4.168<.001$

Table 8.0 exhibits safety rules and procedures $(\beta=0.550, t=8.946)$, safety communication ( $\beta$ $=0.199, \mathrm{t}=3.504)$, and entrepreneur commitment $(\beta=0.184, \mathrm{t}=4.168)$. All three $\mathrm{t}$-values are statistically significant because their corresponding $p$-values $<0.05$. Therefore, safety rules and procedures, safety communication, and entrepreneur commitment are individually useful to the prediction of safety performance. Whereas safety promotion, worker involvement and safety training do not.

The result of this study resembles that of Subramaniam et al (2016) in which management commitment and safety rules and procedures were significantly related to safety compliance. For safety communication, committed SKM entrepreneurs must summarise company's safety rules in a concise, clear list before posting them in several visible locations to serve as a reminder and precaution for all employees.

\section{Implications}

The contribution of this study can be viewed as filling a gap in research studies attempting to identify the drivers of safety performance among Malaysian Bumiputera SMEs. For the theoretical implications, few researchers have previously investigated OHS issues of SKM Bumiputera SMEs. So, this research emphasizes on six components of safety management practices and expounds their contents, resulting in further advancements. Empirical evidence on the effect of safety management practices on SME safety performance serves as a benchmark for Bumiputera SME entrepreneurs in evaluating their performance for each element of safety management attempts. 
Looking at the practical implications, it shows that SKM Bumiputera SME entrepreneurs should train their employees adequately. A poorly trained employee may not be able to meet basic OHS standards at work, leading to a serious accident that injures many employees (Suha et al., 2019).

There is a limitation to research in this study, in the sense that causation could not be inferred since the authors present the study in a correlational nature. Nonetheless, while safety performance can be theorised to trigger the establishment of safety management practises, such a theoretical perspective tends to connote awareness rather than proactivity of the decision-making process.

\section{Conclusion}

It is critical for SMEs to recognise the importance of safety performance in order to generate higher returns by reducing costs incurred to pay out compensation. If workplace safety and health risks are reduced, the country's economic competitiveness will eventually improve. More importantly, this study emphasises the significance of safety management practices in promoting a safe work environment. Unlike most other aspects of a company's operations, the safety effort should be incorporated into practically every program, activity, and department. In other words, if Bumiputera SMEs' safety programs are examined in a holistic and integrated manner, encompassing safety management practices, not only will safety performance improve, but so will productivity, quality, and worker job satisfaction.

\section{Acknowledgements}

This work was supported by the Internal State Fund (DDN) 600-TNCPI 5/3/DDN(03)006/2020) from Universiti Teknologi MARA, Kelantan Branch.

\section{References}

Al Mawli, B., Al Alawi, M., Elazouni, A., \& Al-Mamun, A. (2021). Construction SMEs safety challenges in water sector in Oman. Safety science, 136, 105156.

Asad, M., Kashif, M., Sheikh, U. A., Asif, M. U., George, S., \& Khan, G. U. H. (2021). Synergetic effect of safety culture and safety climate on safety performance in SMEs: does transformation leadership have a moderating role. International journal of occupational safety and ergonomics, 1-18.

Azzahra'Johari, S. F., Rashid, U. K., Safian, E. E. M., \& Nasuredin, J. (2021). Critical Criteria of Women-Owned SMES Performance Using Multi-Attribute Decision Making (MADM) of Analytical Hierarchy Process (AHP). Journal of Innovation Management in Small \& Medium Enterprises, 1-15.

Bernama. (2021). Medac sedia rm20 juta bantu koperasi terjejas. July 8, 2021. Available at: https://www.astroawani.com/berita-bisnes/medac-sedia-rm20-juta-bantu-koperasiterjejas-307308

Bernama (2019). SKM sasar perolehan koperasi RM50 bilion pada 2020. January 21, 2019. Available at: https://malaysiadateline.com/skm-sasar-perolehan-koperasi-rm50-bilionpada-2020/

Bird, F. E., \& Loftus, R. G. (1976). Loss control management. Institute Press.

Breslin, F. C., Kyle, N., Bigelow, P., Irvin, E., Morassaei, S., MacEachen, E., ... \& Amick, B. C. (2010). Effectiveness of health and safety in small enterprises: A systematic review of quantitative evaluations of interventions. Journal of occupational rehabilitation, 20(2), 163-179. 
Caldarescu, G., Tanasievici, G. D., Bejinariu, C., \& Bernevig, M. A. (2021). The influence of economic factors in the management of health and safety specific to SMEs. In MATEC Web of Conferences (Vol. 342). EDP Sciences.

Dawes, J. (2008). Do data characteristics change according to the number of scale points used? An experiment using 5-point, 7-point and 10-point scales. International journal of market research, 50(1), 61-104.

Delery, J. E. (1998). Issues of fit in strategic human resource management: Implications for research. Human resource management review, 8(3), 289-309.

DOSH. (2021). Occupational Safety and Health Master Plan 2021 - 2025 (OSHMP2025). Department of Occupational Safety and Health Malaysia. Available at: https://visionzero.perkeso.gov.my/form/slide2021/Mr.\%20Ahmad\%20Nazri\%20\%20DOSH.pdf

Dugolli, M. (2021). Occupational, health and safety situation at small and medium enterprises in Kosovo, contextual factors, barriers, drivers and intervention process. International Review of Applied Sciences and Engineering, 12(1), 19-28.

Dumitrașciuc, L. F. (2019). How Important Is Education In Creating Successful Entrepreneurs?. Journal of Public Administration, Finance and Law, (16), 88-96.

Eakin, J. M., \& Mykhalovskiy, E. (2003). Reframing the evaluation of qualitative health research: reflections on a review of appraisal guidelines in the health sciences. Journal of evaluation in clinical practice, 9(2), 187-194.

Gao, R., Chan, A. P., Lyu, S., Zahoor, H., \& Utama, W. P. (2018). Investigating the difficulties of implementing safety practices in international construction projects. Safety science, 108, 39-47.

Griffin, M. A., \& Neal, A. (2000). Perceptions of safety at work: a framework for linking safety climate to safety performance, knowledge, and motivation. Journal of occupational health psychology, 5(3), 347.

Hale, A., Heijer, T., Koornneef, F. (2003). Management of safety rules: the case of railways. Safety Science Monitor. 7 (1), 1-11.

Hong, C. C., Ramayah, T., \& Subramaniam, C. (2018). The relationship between critical success factors, internal control, and safety performance in the Malaysian manufacturing sector. Safety Science, 104 (June 2016), 179-188.

Hou, Y., Khokhar, M., Khan, M., Islam, T., \& Haider, I. (2021). Put Safety First: Exploring the Role of Health and Safety Practices in Improving the Performance of SMEs. SAGE Open, 11(3), 21582440211032173.

Iqbal, M., Ahmad, N., Waqas, M., \& Abrar, M. (2021). COVID-19 pandemic and construction industry: Impacts, emerging construction safety practices, and proposed crisis management. Brazilian Journal of Operations \& Production Management, 18(2), 1-17.

Jenkins, D. S., Kane, G. D., \& Velury, U. (2004). The impact of the corporate life cycle on the value-relevance of disaggregated earnings components. Review of Accounting and Finance.

Kelloway, E. K., Kelloway, E. K., \& Cooper, C. L. (Eds.). (2011). Occupational health and safety for small and medium sized enterprises. Edward Elgar Publishing.

Krejcie, R. V., \& Morgan, D. W. (1970). Determining sample size for research activities. Educational \& Psychological Measurement, 30, 607-610.

Lin, C. C., \& Chang, C. H. (2021). Evaluating employee's perception toward the promotion of safety marketing at ports. International Journal of Shipping and Transport Logistics, 13(3-4), 275-299. 
Lu, C. S., Poon, H. Y., \& Weng, H. K. (2018). A safety marketing stimuli-response model of passenger behaviour in the ferry context. Maritime Business Review. 3(4), 354-374.

Newaz, M. T., Ershadi, M., Jefferies, M., \& Davis, P. (2021). Assessing safety management factors to develop a research agenda for the construction industry. Safety science, 142, 105396.

Nordin, A., \& Lada, S. (2020). Faktor Penerimaan Media Sosial Dalam Pemasaran Di Kalangan Industri Kecil Dan Sederhana (IKS) Di Labuan: Social Media Acceptance Factor in Marketing Among Small Medium Enterprises (SME) In LABUAN. Journal of the Asian Academy of Applied Business (JAAAB), 59-59.

Nowrouzi-Kia, B., Nadesar, N., \& Casole, J. (2019). Systematic review: Factors related to injuries in small-and medium-sized enterprises. International journal of critical illness and injury science, 9(2), 57.

Nunnally, J. C. (1978). Psychometric theory. New York, NY: McGraw-Hill.

Othman, A., Ng, W. K., \& Mohamad, N. (2020). Factors of Entrepreneurial Personality Characteristics on Business Failure of SMEs. International Journal of Human and Technology Interaction (IJHaTI), 4(2), 23-30.

Pallant, J. (2013). SPSS survival manual. McGraw-hill education (UK).

Ramos, D., Afonso, P., \& Rodrigues, M. A. (2020). Integrated management systems as a key facilitator of occupational health and safety risk management: A case study in a medium sized waste management firm. Journal of Cleaner Production, 262, 121346.

Roscoe, J.T. (1975) Fundamental Research Statistics for the Behavioural Sciences, 2nd edition. New York: Holt Rinehart \& Winston.

Saunders, M., Lewis, P., \& Thornhill, A. (2009). Research methods for business students. Pearson education.

Sekaran, U., \& Bougie, R. (2019). Research methods for business: A skill building approach. john wiley $\&$ sons.

Sais, R. M. (2020). Direktori Keahlian Angkasa Negeri Kelantan. Personal communication via email, November 18, 2020.

Setyawan, A., Nainggolan, F., \& Fauzi, A. (2021). The Influence of Management Commitment, Leadership, Employee Engagement, and Training on Safety Performance at a Manufacturing Industry in Batam. Journal of Business Studies and Management Review, 4(2), 132-136.

Singh Ghura, A. (2017). A qualitative exploration of the challenges organizations face while working with generation Z intrapreneurs. Journal of Entrepreneurship and Innovation in Emerging Economies, 3(2), 105-114.

Su, W. J. (2021). The Effects of Safety Management Systems, Attitude and Commitment on Safety Behaviors and Performance. International Journal for Applied Information Management, 1(4), 187-200.

Subramaniam, C., Shamsudin, F. M., Zin, M., Mohd, L., Ramalu, S. S., \& Hassan, Z. (2016). Safety management practices and safety compliance in small medium enterprises: Mediating role of safety participation. Asia-Pacific journal of business administration, 8(3), 226-244.

Suha, G., Al-Aghbari, S., \& Sana, Y. (2019). Small Businesses and Lack of Training. 10.13140/RG.2.2.17648.71688.

Sukamani, D., Wang, J., \& Kusi, M. (2021). Impact of safety worker behavior and safety climate as mediator and safety training as moderator on safety performance in construction firms in Nepal. KSCE Journal of Civil Engineering, 25(5), 1555-1567. 
Tremblay, A., \& Badri, A. (2018). Assessment of occupational health and safety performance evaluation tools: State of the art and challenges for small and medium-sized enterprises. Safety science, 101, 260-267.

Ünal, Ö., Akbolat, M., Amarat, M., \& Tilkilioğlu, S. (2019). The role of the human factor in occupational safety and health performance. International Journal of Occupational Safety and Ergonomics, 0(0), 1-17.

Vinodkumar, M. N., \& Bhasi, M. (2010). Safety management practices and safety behaviour: Assessing the mediating role of safety knowledge and motivation. Accident Analysis \& Prevention, 42(6), 2082-2093.

Wahab, S. R., Rajab, A., Shaari, R., Rahman, S. A., \& Saat, M. M. (2014). Manipulation of Safety Training Practices on Organizational Safety Performance: An Evidence in Malaysia's Automotive Industry. International Journal of Trade, Economics and Finance, 5(1), 110113.

Wachter, J. K., \& Yorio, P. L. (2014). A system of safety management practices and worker engagement for reducing and preventing accidents: An empirical and theoretical investigation. Accident Analysis \& Prevention, 68, 117-130.

Wright, P. M., Dunford, B. B., \& Snell, S. A. (2001). Human resources and the resource-based view of the firm. Journal of management, 27(6), 701-721.

Yazici, S., \& Ayazlar, R. A. (2021). Generation Z and Tourism Entrepreneurship: Generation Z's Career Path in the Tourism Industry. In Generation Z Marketing and Management in Tourism and Hospitality (pp. 53-99). Palgrave Macmillan, Cham.

Zohar, D., \& Erev, I. (2007). On the difficulty of promoting workers' safety behaviour: overcoming the underweighting of routine risks. International Journal of Risk Assessment and Management, 7(2), 122-136.

Zulkifly, S. S., Baharudin, M. R., Mahadi, M. R., \& Ismail, S. N. S. (2021a). The Effect of OwnerManager's Safety Leadership and Supervisor's Safety Roles on Safety Performance in SME Manufacturing. Journal of Technology and Operations Management, 16(1), 11-24.

Zulkifly, S. S., Baharudin, M. R., Mahadi, M. R., Hasan, N. H., \& Ismail, S. N. S. (2021b). The Impact of Superior Roles in Safety Management on Safety Performance in SME Manufacturing in Malaysia. Global Business Review, 09721509211049588. 
INTERNATIONAL JOURNAL OF ACADEMIC RESEARCH IN BUSINESS AND SOCIAL SCIENCES

Vol. 12, No. 1, 2022, E-ISSN: 2222-6990 @ 2022 HRMARS 